\title{
Improve Electricity Efficiency by Applying TRIZ
}

\author{
Nikalus Shu Luing Swee, Mum Wai Yip, Chee Sheng Keong, See Chew Tai, and Guat Guan Toh
}

\begin{abstract}
This paper aims to provide a systematic analysis by applying TRIZ to reduce the consumption of household electricity, and nonetheless it does not demote the quality of living. TRIZ tools such as defining engineering system, function analysis, cause and effect chain analysis and contraction matrix are applied in order to discover some feasible and elegant solutions to alleviate the problem. Findings revealed that the problems of high household electricity consumption are owing to the wastage of electricity due to the ignorance behavior, poor layout design of the house, stand-by mode "leak" of electrical appliances and high electricity consumption from old electronic products. The root causes and contradictions are solved by applying contradiction matrix, and inventive principles are recommended, i.e., segmentation, copying, preliminary action, dynamization, intermediary, and parameter changes. Therefore, it can be concluded that TRIZ is a systematic and innovative tool in problem solving.
\end{abstract}

Index Terms-Electricity efficiency, systematic analysis, TRIZ, contradiction matrix.

\section{INTRODUCTION}

As the population of the world continues to grow, the energy consumption in the residential sector has been increasing over the years. The demand for energy usage within household originates from heating and cooling, lighting, charging and stand-by power, cooking, entertainment, electrical appliances and miscellaneous purposes [1], [2]. The rise of electricity consumption not only increases the electricity usage cost, the production and the usage of electricity have also emitted greenhouse gases such as carbon dioxide $\left(\mathrm{CO}_{2}\right)$ and chlorofluorocarbon (CFC). The emission of these greenhouse gases brings significant impact to our health and the environment such as air pollution and global warming. Therefore, energy efficiency is the key solution and most people think of green buildings. Considering the US Department of Energy's finding that commercial and residential buildings together represent more than a third of the primary energy use and more than

Manuscript received January 14, 2014; revised April 29, 2014.

Nikalus Shu Luing Swee is with Department of Computer Science and Mathematics, Tunku Abdul Rahman University College, Malaysia (e-mail: sweesl@acd.tarc.edu.my).

Mun Wai Yip is with Department of Mechanical Engineering, Tunku Abdul Rahman University College, Malaysia (e-mail: yipmw@acd.tarc.edu.my).

Chee Sheng Keong is with Department of Chemistry \& Biology, Tunku Abdul Rahman University College, Malaysia (e-mail: keongcs@acd.tarc.edu.my).

See Chew Tai is with Department of Electronic Engineering, Tunku Abdul Rahman University College, Malaysia (e-mail: taisc@acd.tarc.edu.my).

Guat Guan Toh is with Department of Accounting \& Finance, Tunku Abdul Rahman University College, Malaysia (e-mail: tohgg@acd.tarc.edu.my). two-thirds of electric consumption, energy efficiency is a big deal [3]. Many techniques have been used to block the sun, but conversely, many are also trying to find ways to use the natural sunlight to light up rooms in order to conserve energy. It is an apparent paradox. What are the reasons for the increase of electricity demand and how do we carry out energy (electricity) efficiency right from our home?

TRIZ is a systematic innovation methodology. It is a Russian acronym for "Teoriya Resheniya Izobreatatelskikh Zadatch", equivalent to "Theory of Inventive Problem Solving" in English. TRIZ methodology was founded in 1940's by Genrich Altshuller and his team. He studied intellectual property contained in approximately 200,000 patents. He discovered and organized his study of 40,000 patents according to innovative patterns of design as well as the inventive principles in these innovative solutions [4]. Findings revealed that problems and solutions, patterns of technical evolution were repeated across industries and sciences, and innovations used scientific effects outside the field where they were developed. Therefore, Genrich Altshuller deduced 40 inventive principles [4]-[11]. TRIZ comprises of several essential tools such as defining engineering systems, function analysis, cause and effect chain analysis, trimming, engineering contradiction, substance-field model, Trends of Engineering System Evolutions, ARIZ, and etc. TRIZ uses 40 inventive principles (see Appendix) and 39 parameters (see Appendix) to help inventors to derive many feasible solutions [4]-[11].

\section{PRoblem STATEMENT}

The cost of electricity usage is increasing with regard to the increase of energy usage at home. Reducing energy usage at home saves money. In addition to that, reducing household energy usage also helps reduce greenhouse gases and pollution caused by emission from non-renewable sources of energy. The following is the detail of the systematic analysis.

\section{TRIZ MODEL AND TOOLS}

\section{A. TRIZ Flow Process}

The TRIZ flow process is shown in Fig. 1. First and foremost, research and brainstorming help to identify the original problem to resolve, and this is followed by function analysis, cause and effect chain analysis and engineering contradiction. Finally, contradiction matrix is used to locate the specific inventive principles, which will then lead to specific solution(s) [4], [9].

\section{B. Engineering System Definition}

An Engineering System consists of several components 
that are interacted among each other. These components are commonly accepted as system components (subsystems) that are listed in Fig. 2. Along with subsystems, there are also interactions between engineering system and external entities called supersystems. Supersystems are not designed as part of the Engineering System; however, they can influence or impact the Engineering System [4], [5]. Fig. 2 shows the engineering system of the electricity components in a building.

\begin{tabular}{l} 
- Research \& Brainstorming \\
- Engineering System Definition \\
\hline - Caunction Analysis \& Effect Chain Analysis \\
\hline - Engineering Contradiction \\
\hline - Specific Inventive Principle (s) \\
\hline - Specific Solution(s)
\end{tabular}

Fig. 1. TRIZ flow process.

\begin{tabular}{|l|l|}
\hline $\begin{array}{l}\text { Subsystems/System } \\
\text { Components }\end{array}$ & $\begin{array}{l}\text { electrical appliances, users, circuit, fuse box, } \\
\text { meter, wall power points, walls }\end{array}$ \\
\hline Supersystem & $\begin{array}{l}\text { Layout of house, location, knowledge, seasons, } \\
\text { weather, size of house, number of windows, } \\
\text { direction of windows, sunlight, wind/air, heat, } \\
\text { harmful gases }\end{array}$ \\
\hline
\end{tabular}

Fig. 2. Engineering systems.

\section{Function Analysis}

Function analysis shows the interactions between two or more subsystems (Engineering System components) which are listed in Fig. 3. These interactions are called functions. Functions are simply actions between two components, i.e., a subject and an object in which the subject acts upon and modifies a parameter(s) of the object [4]. Two main types of functions are useful function and harmful function. As for useful function, it comprises of "normal", "insufficient", and "excessive" functions [4], [5]. Function model gives a pictorial representation of the engineering system. It indicates harmful, excessive or insufficient functions that require more attentions.

\section{Cause and Effect Chain Analysis (CECA)}

Fig. 4 shows the CECA diagram. CECA is a vital tool in the TRIZ methodology. It helps identify the right root cause(s) pertaining to the problem. If wrong root causes are obtained, the solution derived may not be effective. Elementarily, CECA is very similar to "5 Whys". We prompt for causes continuously for the problem from high level causes to low level causes by asking "the question "why?".

From the CECA, the validated root causes are the wastage of electricity due to the ignorance behavior of the people, poor layout design of the house, stand-by mode "leak" of electrical appliances and high electricity consumption from old electronic products (non-energy saving).

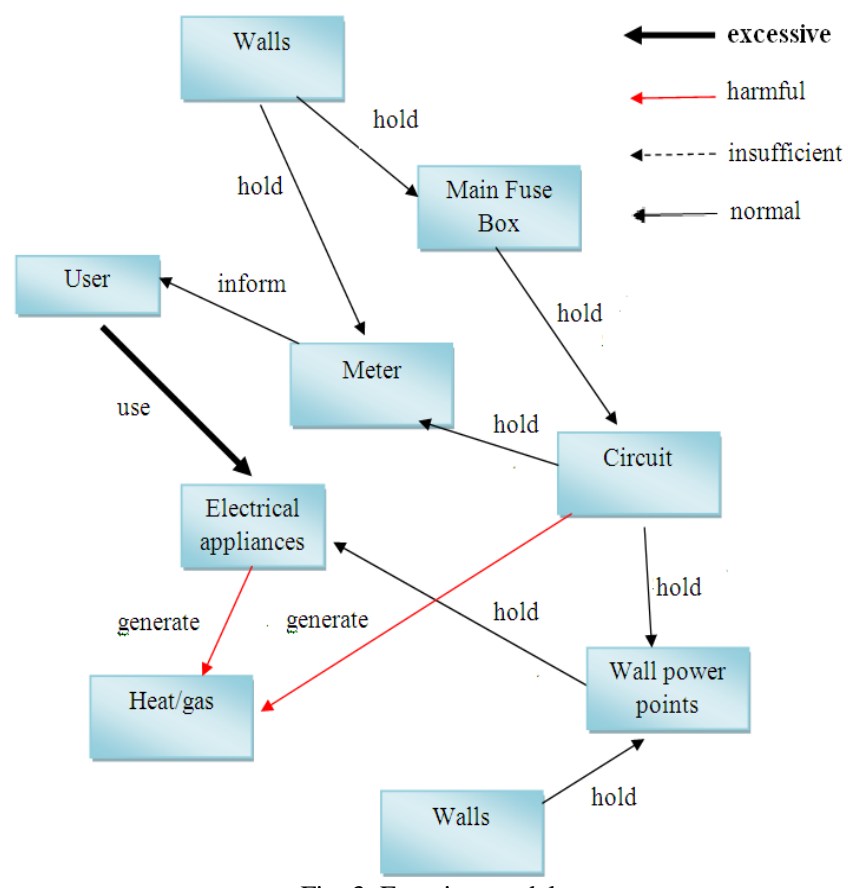

Fig. 3. Function model.

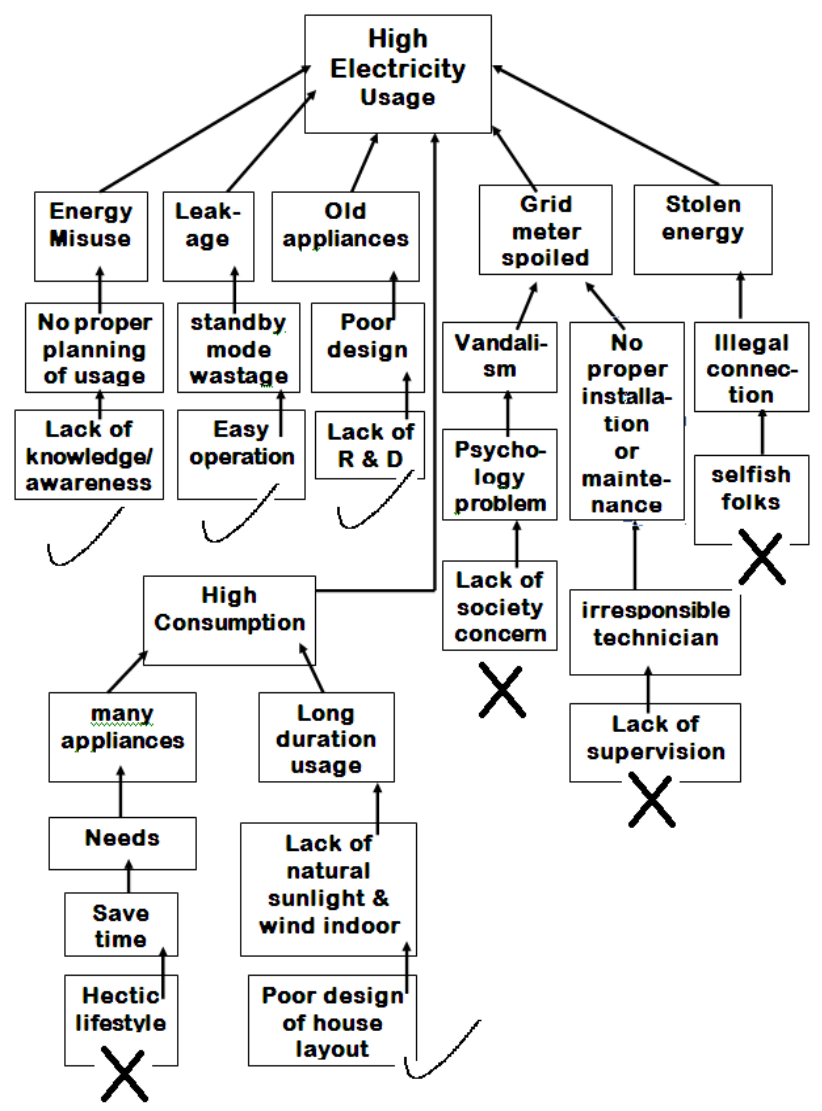

Fig. 4. Cause and effect chain analysis.

\section{E. Engineering Contradictions, Contradictions Matrix} and Inventive Principles

Contradiction always exists in our daily life, i.e., plus and minus, differential and integral in mathematics; positive and negative electrical charges in physics and etc. [12]. The most effective solutions are achieved when an engineer or an inventor solves a technical problem that contains contradiction [11]. Engineering Contradiction denotes that if 
one characteristic or parameter of the system is to be improved (improving parameter) and causes another characteristic or parameter of the system to deteriorate (worsening parameter). These parameters are translated into one of the 39 engineering parameters in TRIZ. TRIZ approach is to eliminate and solve the contradiction, also better known as engineering contradiction [5]. Engineering contradictions can be formulated based on the cause and effect chain analysis. The contradiction is included in any process of solving the inventive problems. Therefore, contradiction matrix or Altshuller matrix is used to solve the contradiction that developed by Altshuller [9], [10]. Fig. 5 shows the Altshuller's Contradiction Matrix in which inventive principles will be suggested based on a mapping process between a good and a bad parameter.

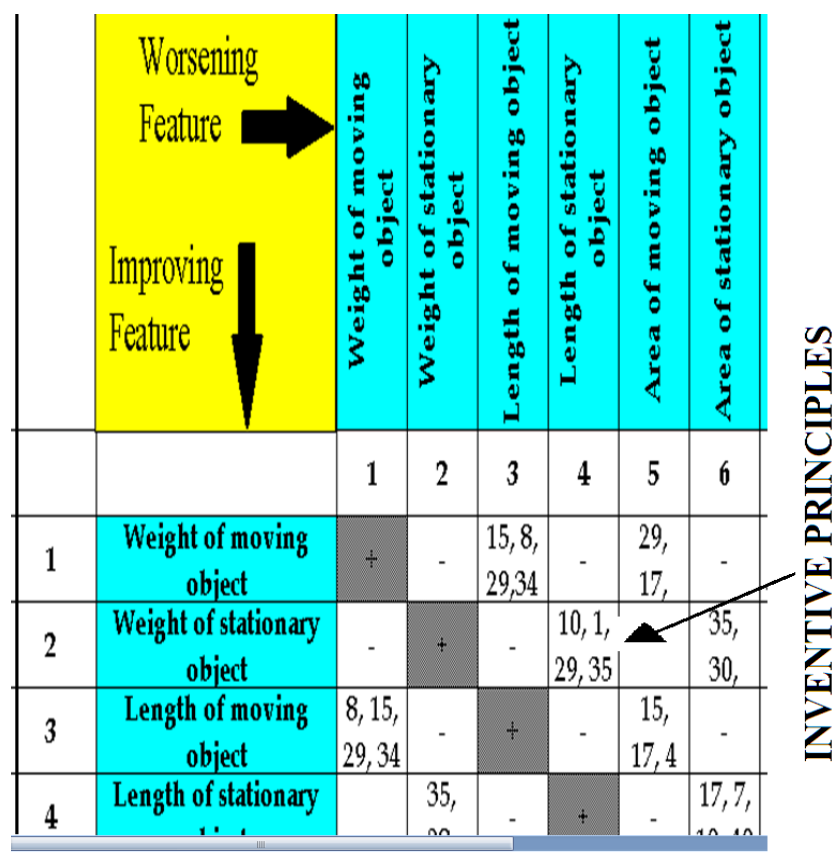

Fig. 5. Altshuller's contradiction matrix.

The following engineering contradictions are formulated based on the root causes in CECA [9], [10].

\section{1) Engineering contradiction 1}

If a user can use house electrical appliances in good and responsible manner, then the wastage of energy can be reduced, but, the user may feel irritated and inconvenient to turn the appliances on and off regularly.

Table I shows the inventive principles recommended based on the engineering contradiction 1.

TABLE I: INVENTIVE PRINCIPLES OF ENGINEERING CONTRADICTION 1.

\begin{tabular}{|l|l|l|}
\hline $\begin{array}{l}\text { Altshuller Contradiction } \\
\text { Matrix }\end{array}$ & $\begin{array}{l}\text { Inventive } \\
\text { Principles }\end{array}$ & $\begin{array}{l}\text { Suitable } \\
\text { Inventive } \\
\text { Principles }\end{array}$ \\
\hline $\begin{array}{l}\text { Improving parameter: } \\
\text { Reduce energy wastage } \\
\text { (\#21 Power) }\end{array}$ & $\# 26$ (Copying) & $\begin{array}{l}\# 35 \text { (Parameter } \\
\text { changes) }\end{array}$ \\
$\begin{array}{l}\text { Xorsening parameter: } \\
\text { Convenience of use (\#33 } \\
\text { Ease of Operation) }\end{array}$ & $\begin{array}{l}\# 35 \text { (Parameter } \\
\text { changes) }\end{array}$ & $\begin{array}{l}\# 10 \text { (Preliminary } \\
\text { action) }\end{array}$ \\
\hline
\end{tabular}

\section{2) Engineering Contradiction 2}

If the windows and walls of a house can be mobilized, then more natural sunlight and wind can be obtained, but, it may generate excessive heat and dust in the house.

Table II shows the inventive principles recommended based on the engineering contradiction 2 .

TABLE II: INVENTIVE PRINCIPLES OF ENGINEERING CONTRADICTION 2.

\begin{tabular}{|l|l|l|}
\hline $\begin{array}{l}\text { Altshuller } \\
\text { Contradiction Matrix }\end{array}$ & $\begin{array}{l}\text { Inventive } \\
\text { Principles }\end{array}$ & $\begin{array}{l}\text { Suitable Inventive } \\
\text { Principles }\end{array}$ \\
\hline $\begin{array}{l}\text { Improving parameter: } \\
\text { Directions of windows } \\
\text { and walls (\#3 Angle of } \\
\text { moving objects) }\end{array}$ & $\# 1$ (Segmentation) & $\# 1$ (Segmentation) \\
$\qquad \begin{array}{l}\text { X } \\
\text { Worsening parameter: }\end{array}$ & $\begin{array}{l}\# 17 \text { (Dnother } \\
\text { Dimension) }\end{array}$ & $\# 24$ (Intermediiary) \\
$\begin{array}{l}\text { Excessive heat and dust } \\
\text { affecting life (\#30 } \\
\text { Object Affected } \\
\text { Harmful Factors) }\end{array}$ & $\# 24$ (Intermediary) & \\
\hline
\end{tabular}

\section{3) Engineering Contradiction 3}

If the house electrical appliances have better $\mathrm{R} \& \mathrm{D}$ process, then more energy saving product can be produced, but, these energy saving products might be more costly and require more complex manufacturing process.

Table III shows the inventive principles recommended based on the engineering contradiction 3 .

TABLE III: INVENTIVE PRINCIPLES OF ENGINEERING CONTRADICTION 3.

\begin{tabular}{|l|l|l|}
\hline $\begin{array}{l}\text { Altshuller } \\
\text { Contradiction Matrix }\end{array}$ & $\begin{array}{l}\text { Inventive } \\
\text { Principles }\end{array}$ & $\begin{array}{l}\text { Suitable Inventive } \\
\text { Principles }\end{array}$ \\
\hline $\begin{array}{l}\text { Improving parameter: } \\
\text { Save energy }\end{array}$ & \#26 (Copying) & \#26 (Copying) \\
X Power) & $\begin{array}{l}\text { \#34 (Discarding } \\
\text { and recovering) }\end{array}$ & \\
Worsening parameter: & $\begin{array}{l}\text { \#10 } \\
\text { (Preliminary } \\
\text { action) }\end{array}$ & \\
$\begin{array}{l}\text { (\#32 Eamplex manufacturing of } \\
\text { Manufacture) }\end{array}$ & & \\
& & \\
\hline
\end{tabular}

\section{TRIZ SOLUTIONS AND DISCUSSION}

\section{A. Proposed Solutions for Engineering Contradiction 1}

With regard to ignorance behavior of users, the followings are the recommended solutions.

\section{1) Solution 1}

Selected Inventive Principle \#35 (Parameter changes) is to change the degree of flexibility. After thorough discussion with field specialists, Inventive Principle "Copying" is not suitable for the engineering contradiction 1. We suggest that the electrical products such as air-conditioning, fan and lighting should have a timer to control the activation and deactivation of these electricity appliances. Therefore, users can set the time for these appliances to turn on and off automatically without having to do it manually. As for lighting, photoelectric control sensors can be installed to turn on or off without the involvement of users [13].

\section{2) Solution 2}

In accordance to the Inventive Principle \#10 (Preliminary 
action, "Do it in advance"), it suggests to perform the required change of an object (either fully or partially) before it is needed. Ignorance behavior of users must be rectified by creating awareness of energy efficiency or proper use of electricity. All users should be taught to turn off any unused electrical appliances instead of setting to standby mode. According to Meier [1], standby mode electronics will still consume $9 \%$ to $26 \%$ of energy in a day. In some countries such as US, local power utilities conduct information and motivation campaigns to raise consumer's awareness and encourage the purchase of equipment with reduced standby consumption. Other method of reducing standby power consumption in many appliances is the adoption of technological innovations. It is estimated that redesigning appliance circuits can reduce standby power consumption up to 90 per cent [1]. Turn off (no standby mode) TV and modem can save $15 \%$ and $50 \%$ of electricity respectively [14].

\section{B. Proposed Solutions for Engineering Contradiction 2}

With respect to the layout of a house or building on improving energy efficiency, the following is the recommended solution.

\section{1) Solution 3}

Selected inventive principles are Inventive Principle \#1 (Segmentation) and Inventive Principle \#15 (Dynamization). "Segmentation" suggests to increase the degree of fragmentation, "Dynamization" suggests that if an object (or process) is rigid or inflexible, make it movable or adaptive and "Intermediary" proposes to use an intermediary carrier articles or intermediary process. Other inventive principle is not suitable for the problem after profound consideration. Thus, engineers can design duct or path or introducing an air-well in the middle of high-rise that can change the direction of wind and light into each residence. For housing such as high-rise, the lower level residences always face the problems of blockage of sunlight and wind by another block of high-rise nearby. Therefore, engineers can install a portable and adjustable sunlight collector to harvest the sunlight from the roof of the building and use the reflection theory to direct the sunlight to every unit of the apartment through clerestory windows. Besides that, installing fragmented sliding glass doors or walls may increase the penetration of sunlight [15]. In addition, an air duct can be designed to direct the flow of wind into the house/building [16]. This can increase the air movement and prevent the heat trapped inside the house. Therefore, the house will become cooler and the frequency of switching on fan or air-conditioning can be reduced. Furthermore, Dr. Koster and his team members developed a fixed louver system between a double glass-facade. This design allows heat reflection during the hottest months while still permitting proliferation of daylights into rooms [17]. Pertaining to the dust brought in by the wind into a home/building. Shrubs or trees can be planted at the perimeter of the building. Shrubs or trees act as an intermediary agent and natural windbreaks to filter or shade dusts carried by the wind [18]. Thus, the dust entering the building can be controlled effectively.

\section{Proposed Solutions for Engineering Contradiction 3}

How is better R \& D helping to improve energy efficiency? The following is the recommended solution.

\section{1) Solution 4}

Selected Inventive Principle \#1 (Copying) suggests to use simpler and inexpensive copies instead of an expensive, unavailable or fragile objects. We are aware of abundant of new energy saving and solar-powered appliances in the market [19], [20]. In addition, people can always install a simpler, smaller and cheaper form of renewable energy generator like solar power in which it can generate electricity and store in a rechargeable battery[21], [22]. For instance, a fully charged $12 \mathrm{~V}-50 \mathrm{AH}$ battery can generate 600 watt-hour of electricity. The battery can power at least 5 units of 15 Watts energy saving electrical appliances (light bulbs) for 8 hours. It is sufficient to power several energy saving lightings daily [23], [24]. Thus, this renewable energy will indeed help improve energy efficiency significantly.

\section{CONCLUSION}

Rising usage of electricity worldwide deserves more attention from the public and the governments to source for effective remedies. In this case study, the problem can be contained and lessened by applying TRIZ tools particularly the inventive principles such as segmentation, preliminary action, parameter changes and copying. TRIZ helps inventors generate more feasible ideas or concepts systematically which may lead to elegant solutions. TRIZ requires a vigorous cooperation between field specialists and TRIZ consultant so as to find the right root causes and derive ideas or effective solutions. It can be concluded that TRIZ is a systematic and an innovative problem solving methodology.

\section{APPENDIX}

\section{Inventive Principles}

\#1. SEgMENTATION

\#2. TAKING OUT / EXTRACTION

\#3. LOCAL QUALITY

\#4. ASYMMETRY

\#5. MERGING / COMBINATION

\#6. UNIVERSALITY

\#7. "NESTED DOLL"

\#8. ANTI-WEIGHT / COUNTER-WEIGHT

\#9. PRELIMINARY ANTI ACTION / PRIOR COUNTER-ACTION \#10. PRELIMINARY ACTION / PRIOR ACTION

\#11. BEFOREHAND CUSHIONING / PRIOR CUSHIONING

\#12. EQUI-POTENTIALITY / REMOVE TENSION

\#13. 'THE OTHER WAY ROUND'

\#14. SPHEROIDALITY-CURVATURE

\#15. DYNAMICS

\#16. PARTIAL OR EXCESSIVE ACTIONS

\#17. ANOTHER DIMENSION

\#18. MECHANICAL VIBRATION

\#19. PERIODIC action

\#20. CONTINUITY of useful action

\#21. SKIPPING / Hurrying

\#22. 'BLESSING in Disguise' 


\section{\#23. FEEDBACK}

\#24. INTERMEDIARY

\#25. Self- Service

\#26. COPYING

\#27. CHEAP / SHORT LIVING

\#28. MECHANICS SUBSTITUTION / ANOTHER SENSE

\#29. PNEUMATICS AND HYDRAULICS / FLUIDITY

\#30. FLEXIBLE SHELLS AND THIN FILMS / THIN \& FLEXIBLE

\#31. Porous MATERIALS / Holes

\#32. COLOR CHANGES

\#33. HOMOGENEITY

\#34. DISCARDING AND RECOVERING

\#35. PARAMETER CHANGES

\#36. PHASE TRANSITIONS

\#37. THERMAL EXPANSION / RELATIVE CHANGE

\#38. STRONG OXIDANTS / ENRICHED ATMOSPHERE

\#39. INERT ATMOSPHERE / CALMED ATMOSPHERE

\#40. COMPOSITE MATERIALS / COMPOSITE STRUCTURES

\section{System Parameters}

\#1. WeIGHT OF MOVING OBJECT

\#2. Weight OF Stationary OBJECT

\#3. LENGTH (OR ANGLE) OF MOVING OBJECT

\#4. LENGTH (OR ANGLE) OF STATIONARY OBJECT

\#5. AREA OF MOVING OBJECT

\#6. AREA of Stationary OBJect

\#7. VOLUME OF MOVING OBJECT

\#8. VOLUME OF STATIONARY OBJECT

\#9. SPEED

\#10. FORCE (a.k.a. TORQUE)

\#11. STRESS / PRESSURE

\#12. SHAPE

\#13. STABILITY OF THE OBJECT's COMPOSITION

\#14. STRENGTH

\#15. DURATION OF ACTION OF MOVING OBJECT

\#16. DURATION OF ACTION OF STATIONARY OBJECT

\#17. TEMPERATURE

\#18. ILLUMINATION INTENSITY

\#19. USE OF ENERGY BY MOVING OBJECT

\#20. USE OF ENERGY BY STATIONARY OBJECT

\#21. POWER

\#22. LOSS OF ENERGY

\#23. LOSS OF SUBSTANCE

\#24. LOSS OF INFORMATION

\#25. LOSS OF TIME

\#26. QUANTITY OF SUBSTANCE

\#27. RELIABILITY (ROBUSTNESS)

\#28. MEASUREMENT ACCURACY

\#29. MANUFACTURING PRECISION (CONSISTENCY)

\#30. OBJECT AFFECTED HARMFUL FACTORS

\#31. OBJECT GENERATED HARMFUL FACTORS

\#32. EASE OF MANUFACTURE (MANUFACTURABILITY)

\#33. EASE OF OPERATION (MANUFACTURABILITY)

\#34. EASE OF REPAIR (REPAIRABILITY)

\#35. ADAPTABILITY OR VERSATILITY

\#36. DEVICE COMPLEXITY

\#37. DifFiculty OF DETECTING AND MEASURING

\#38. EXTENT OF AUTOMATION

\#39. PRODUCTIVITY

\section{REFERENCES}

[1] A. Meier, "Standby power - a quiet use of energy," CADDET Energy Efficiency Newsletter, no. 4, 1999.

[2] A. Meier and L. Rainer, "The miscellaneous electrical energy use in homes," Energy-The International Journal, vol. 17, no. 5, pp. 509-518, 1992.

[3] M. Stromberg, "Green grow the buildings," Planning, vol. 71, no. 7, pp. 16-17, 19-21, 2005.

[4] T. S. Yeoh, T. J. Yeoh, and C. L. Song, TRIZ- Systematic Innovation in Manufacturing, Selangor: Firstfruits, 2009.

[5] A. A. Guin, A. V. Kudryavtsev, V. Yu. Boubentsov, and A. Seredinsky, Theory of Inventive Problem Solving, First Fruits, 2009.

[6] D. Mann, Hands-On Systematic Innovation, Belgium: CREAX Press, 2003.

[7] D. Mann, Hands-On Systematic Innovation for Business and Management, Devon: Lazarus Press, 2007.

[8] E. M. Smith, "From Russia with TRIZ," Mechanical Engineering, Academic Research Library, p. D18, 2003.

[9] G. S. Altshuller, The Innovation Algorithm, TRIZ Systematic Innovation and Technical Creativity, Worcester, MA: Technical Innovation Centre, 2000.

[10] G. S. Altshuller, 40 Principles, TRIZ Keys to Technical Innovation, Worcester, MA: Technical Innovation Centre, 2002.

[11] J. Terninko, A. Zusman, and B. Zlotin, Systematic Innovation: An Introduction to TRIZ, New York, NY: CRC Press, 2010.

[12] S. D. Savransky and C. Stephan, "TRIZ: Methodology of inventive problem solving," The Industrial Physicist, 1996.

[13] P. J. Littlefair and A. Motin, "Lighting controls in areas with innovative daylighting systems: a study of sensor type," Lighting Res\& Technol., vol. 33, no. 1, pp. 59-73, 2001.

[14] P. A. D. V. Raj, M. Sudhakaran, and P. P. D. A. Raj, "Estimation of standby power consumption for typical appliances," Journal of Engineering Science and Technology Review, vol. 2, no. 1, pp. 71-75, 2009.

[15] J. O'Connor, E. Lee, F. Rubinstein, and S. Selkowitz, Tips for Day Lighting with Windows, Ernest Orlando Lawrence, Berkeley National Laboratory, 1997.

[16] The Fundamentals Volume of the ASHRAE Handbook, Ashrae, Inc., Atlanta, GA, USA, 2005

[17] D. Fong, "Green ideas," Lighting Design + Application, vol. 35, no. 9, pp. 22, 2005.

[18] P. H. Patterson and Adrizal, "Management strategies to reduce air emissions: Emphasis-dust and ammonia," Journal of Applied Poultry Research, vol. 14, no. 3, p. 638, 2005.

[19] Saving Electricity in a Hurry, Paris, International Energy Agency, 2005.

[20] Energy Savings with a Solar Blanket, Hair Clips, and Curtain Rods, the Simple Dollar, Newstex 2010.

[21] C. Anderson, "At home with solar power," Mother Earth News, vol. 195 , p. 17, 2003.

[22] J. Gulland and W. Milne, "Choosing renewable energy," Mother Earth News, vol. 227, p. 89, 2008.

[23] B. Osende and J. Abraham, "Small-scale use of solar power in remote, developing regions: A case study," Journal of Sustainable Development, vol. 4, no. 3, p. 3, June 2011.

[24] J. David, "The good life off the grid: The wonders of 12 volts," Countryside and Small Stock Journal, vol. 88, no. 4, p. 43, Jul/Aug 2004.

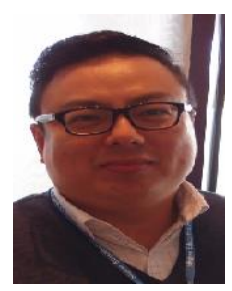

N. S. L. Swee is a program leader and a senior lecturer at Tunku Abdul Rahman University College, Penang Branch Campus, Malaysia. He received BSc degree in information \& computer sciences from National University of Singapore in 1997, and finished a MBA program from Nottingham Trent University, UK in 2001.

He is specifically interested in application of TRIZ and also provides TRIZ workshop to tertiary students, university lecturers and industry folks.

$\mathrm{Mr}$. Swee is a member of International Association of Computer Science and Information Technology (IACSIT). He is also a member of TRIZ Association of Malaysia. He is a certified TRIZ Level 1 Instructor, Level 1 and II Practitioner. He has received awards from Microsoft (Microsoft Certified Technology Specialist) and IBM (IBM Certified Application Developer). 


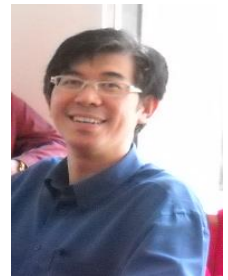

Yip Mum Wai graduated with a diploma in materials engineering from Tunku Abdul Rahman College in 1997 and a MSc degree in manufacturing systems engineering from University of Warwick, United Kingdom in 1998. In 2008, he was awarded an engineering doctorate in engineering business management (Specializing in knowledge management) from Business Advanced Technology Centre, University Technology Malaysia, Malaysia.

$\mathrm{He}$ is an associate dean of mechanical engineering division at Tunku Abdul Rahman University College, Malaysia. He is a certified knowledge management facilitator and practitioner, a certified TRIZ practitioner, a senior member of International Association of Computer Science and Information Technology (IACSIT) and a member of Malaysia TRIZ Innovation Association. He has presented many papers in the field of engineering management especially in $\mathrm{KM}$ in many international conferences in China and Indonesia. He is also a reviewer and an editorial board member of international journals.

Dr. Yip has a lot of experience in research. He has been given a grant by the Ministry of Higher Learning Institution to conduct a research in the implementation of Knowledge Management (KM) in SME in Malaysia.

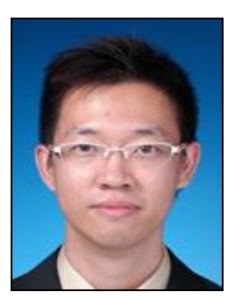

Chee Sheng Keong holds a degree in chemistry and biology and a master degree in environmental science majoring in integrated water resource management and currently pursuing $\mathrm{PhD}$ in education in the area of thinking skill. $\mathrm{He}$ is a certified TRIZ Level 1 instructor, member of Malaysia TRIZ Innovation Association and Malaysian Institute of Chemistry (IKM). He has been actively conducting seminars on leadership, motivation, team building, and study skills for secondary and undergrad students. His passion for innovation in education led him to become a certified level 1 TRIZ trainer. Since then, he has conducted TRIZ training for students in university level and college level. He is presently a chemistry lecturer with Tunku Abdul Rahman University College.

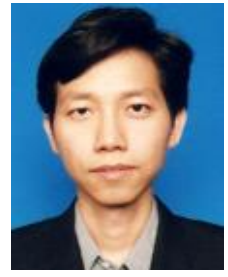

See Chew Tai holds a degree in electrical and electronic and a master degree in information technology. He is a certified TRIZ Level 1 instructor, member of Malaysia TRIZ Innovation Association. He conducts TRIZ training for students in university level and college level. He is presently a lecturer with Tunku Abdul Rahman University College.

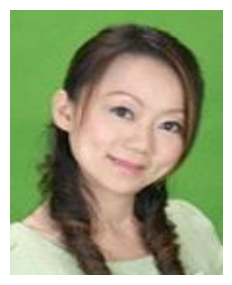

Janice Toh Guat Guan holds a degree from University of Malaya, MSc degree from University of Leicester and a $\mathrm{PhD}$ degree from University of Science Malaysia. She is currently a deputy branch head in Tunku Abdul Rahman University College, Penang Branch Campus. She has taught various management and finance courses as well as presented several finance papers at national finance and management conferences.

She is also a Certified Triz Level 1 Instructor. Recently in 2009, she has presented a paper entitled "Do Malaysian Investors' Judgment Exhibit Reference Dependence?" in the 8th Asian Academy of Management Conference at Hyatt Resort Hotel in Kuantan, Pahang and has been awarded the "Best Paper Award".

She strongly upholds the life-long learning spirit and has continued to explore her research not only in the area of behavioural finance, but also in learning and thinking skills. 